\title{
EDUCATIONAL EFFECTIVITY OF POSTERS IN TECHNICAL EDUCATION OF SECONDARY SCHOOL PUPILS
}

\author{
Pavel DOSTÁL*, Ostravská univerzita, Česká republika
}

Přijato: 24. 3. 2020 / Akceptováno: 20. 5. 2020

Typ článku: Výzkumný článek

DOI: $10.5507 /$ jtie.2020.010

Abstract: Posters are traditional teaching aids and have been used in technical education for many years. But do they really have the expected educational effect? Do they still contribute to raising the knowledge level of children, whose perception is determined by digital technologies? The paper presents the results of a quantitative research on the educational effectiveness of posters with technical content, where the sample was represented by approximately 500 pupils of older school age. The main research method was a natural pedagogical experiment, where the application of created posters corresponded to the independent variable and the level of knowledge was assigned to the dependent variable. A statistically significant increase in knowledge during oneyear experiment was indicated only for a poster containing the least amount of information.

Key words: poster, educational effectivity, elementary school, research.

\section{EDUKAČNÍ EFEKTIVITA PLAKÁTŮ V TECHNICKÉM VZDĚLÁVÁNÍ ŽÁKŮ DRUHÉHO STUPNĚ ZÁKLADNÍ ŠKOLY}

Abstrakt: Plakáty jsou tradiční učební pomi̊ckou a v technickém vzdělávání se využivají už dlouhá léta. Mají však opravdu ten vzdělávaci účinek, jaký je od nich očekáván? Přispívají i v současnosti ke zvýšení úrovně vědomostí dètí, jejichž vnímání je determinováno digitálními technologiemi? Článek prezentuje výsledky kvantitativního výzkumu edukačni efektivity plakátů s technickým obsahem, kdy výběrovým souborem bylo přibližně 500 žákủ staršího školního věku. Hlavni metodou výzkumu byl přirozený pedagogický experiment, kde nezávisle proměnou byla aplikace vytvořených plakátù, závisle proměnnou byla úroveň vědomostí. Statisticky významný prírůstek vědomostí byl po rok trvajícím experimentu indikován pouze u plakátu s nejmenším množstvím obsažených informaci.

Klíčová slova: plakát, edukační efektivita, základní škola, výzkum.

*Autor pro korespondenci: pavel.dostal@osu.cz 


\section{1 Úvod}

Plakát může být definován jako potištěný papír připevněný ke stěně nebo jinému svislému povrchu obsahující grafické a textové prvky, př́ípadně pouze grafické prvky nebo pouze text (Gosling, 1999), př́ípadně jako samostatný list zobrazující poselství připevněný k existujícímu povrchu (Rickards, 1970). Někdy je také zdůrazňováno (např̀. Hubenthal, 2011), že musí být několikanásobně vyroben. To však není v souladu s některými metodami využití plakátů ve vzdělávání, např́iklad kdy autory plakátů jsou sami žáci či studenti (Eker, 2016; Hasio, 2015; Oliveira, 2008; O’Neil, 2001).

Plakáty jsou vytvářeny nejen s důrazem na obsah, nýbrž také na zpo̊sob jeho prezentace. $Z$ výše uvedené definice je patrné, že obsah plakátů může být prezentován s využitím textových a mimotextových komponent. Terminologie související s mimotextovými prvky v učebních pomůckách není jednotná. Jsou pro ně používány různé pojmy, v anglicky psané literatuře např́klad picture (Peeck, 1993), graphic element (Gosling, 1999) illustration (Boling, 2004), visual text (Väisänen, 2005), visual display (Cook, 2006), v česky psané literatuře např́klad neverbální informace (Wahla, 1983), obrazový materiál (Mareš, 2001), grafická informace (Hrabí, 2006), vizuální informace (Novotný, 2007), vizuálie (Spousta, 2007), vizuální prostředky (Pešková, 2012), přičemž přestože autoři tyto pojmy používají v různém kontextu, můžeme je do značné míry chápat jako synonymická označení. Janko (2012) usiluje o zavedení pojmu nonverbální prvek, přičemž tento pojem definuje jako zjednodušenou vnějši obrazovou reprezentaci fenoménů, která může pocházet z různých oblastí vědy, kultury umění apod. Konkrétně se jedná o fotografie, náčrty, kresby, malby, mapy, plány, grafy, schémata, tabulky, geometrické útvary, piktogramy aj. (Janko, 2012).

Historie využití nonverbálních prvků jako didaktického prostředku je dlouhá, literatura na toto téma je k dispozici (např. Ringshausen, 1976; Timmers, 1998) a není cílem tohoto článku se jí podrobně věnovat, nicméně určitě zde stojí za připomenutí průkopnické dílo Jana Amose Komenského Orbis sensualium pictus (první vydání 1658).

Plakáty jsou v současnosti hojně využívaným médiem, které má sloužit k naplnění různorodých cílů. Hlavní funkce plakátů můžeme shrnout do tří oblastí:

- motivační;

- $\quad$ estetické;

- edukační.

U plakátů, se kterými se běžně setkáváme ve veřejném prostoru, obvykle převažuje funkce motivační. Cílem plakátů např́iklad může být vnější motivace $\mathrm{k}$ nákupu nějakého zboží nebo služeb, k návštěvě umělecké či sportovní produkce, k volbě politika či politické strany apod., funkce edukační je obvykle potlačena. Naopak ve vzdělávacích institucích nabývá edukační funkce plakátů na významu, nicméně ani funkci motivační a estetickou nelze opomíjet. Významu prostředí a jeho vlivu na žáky je věnována značná pozornost (např. David, 1975; Kohoutek, 1998; Stone, 1998; Martin, 2002; Oblinger, 2006).

V této souvislosti vyvstává také otázka, zda vliv plakátů umístěných ve školách může být negativní. Bylo indikováno, že velké množství vizuálních podnětů v učebnách může mít za následek ztrátu pozornosti a snížení výkonu při početních nebo pamětových úkolech, přičemž bylo konstatováno, že tento efekt je závislý na věku dětí. Snížení výkonu související s nezralou regulací soustředění bylo indikováno u dětí v předškolním a mladším školním věku, přičemž s věkem se postupně snižuje (Fisher, 2014). 
Pro design edukačních plakátů Hubenthal (2011) zdůrazňuje následující atributy:

- vizuální atraktivita (umělecký design, barvy, typ písma, rozvržení textových a nonverbálních prvků, velikost, kvalita atd. - přispívá $\mathrm{k}$ celkové estetice ve tř́dě, přitahuje pozornost žáků, zvyšuje motivaci učitelů plakát aplikovat);

- vazba na kurikulum (poskytnutí prímé i nepřímé vazby na aktuálně probírané téma, klíčový faktor při rozhodování učitelů zda plakát aplikovat);

- $\quad$ ř̌iměreně zjednodušené poselství (vzhledem ke statické dvourozměrné povaze plakátů musí být obsah přiměřeně zjednodušen s ohledem na způsob využití plakátu ve výuce a kognitivní možnosti žáků);

- vyváženost textu a nonverbálnich prvků (souvisí se způsobem využití plakátů, pokud např́klad má žák primárně vnímat plakát z lavice, musí být obrázky přiměřeně velké);

- vyvolávat otázky (sdělení plakátu nemusí být uzavřené, ale může aktivizovat zájem o další poznání - např́íklad formulovanými otázkami, nedokončenými ilustracemi atd.);

- dalš́ zdroje informací (je zde možnost rozširirit dvourozměrný statický prostor plakátu o další, dnes většinou elektronické, zdroje informací - např. URL, QR kód atd.) (Hubenthal, 2012).

Množství plakátů, které jsou ve vzdělávání využívány, implikuje množství metod jejich využití, nicméně způsoby aplikace edukačních plakátů ve školách zde můžeme pro přehlednost zjednodušeně rozdělit do čtyř skupin:

1. Plakáty jsou vytvářeny žáky či studenty - této metodě je $\mathrm{v}$ zahraniční literatuře věnována relativně velká pozornost. Autoři obvykle zdůrazňují přednosti této metody. Žáci či studenti se při tvorbě plakátu učí pracovat $\mathrm{s}$ informacemi, od vyhledávání potřebných zdrojů informací, přes jejich shrnutí, vizuální vyjádření až po následnou prezentaci, přičemž tvorba plakátů umožňuje pracovat s již dosaženými znalostmi daného tématu, s novými informacemi a se vzájemnými vztahy mezi těmito informacemi. Př́́prava plakátů se také může skládat z činností procvičujících zručnost žáků (napřr. stř́hání a lepení obrázků). Při využití skupinové tvorby a prezentace plakátů je zdůrazňován význam interakcí mezi žáky, možnost aktivně se učit navzájem a rozvoj jejich komunikativních kompetencí (Eisen, 1998), rozvoj prezentačních dovedností, př́padně s akcentací pozitivního prrínosu ke klimatu ve třídě (O’Neil, 2001).

2. Krátkodobé - v tomto př́ípadě jsou plakáty aplikovány $\mathrm{v}$ učebně po dobu, kdy jejich obsah koreluje s aktuálně probíraným učivem. Typické jsou př́pady, kdy učitelé prímo během výuky (nebo před zahájením výuky) plakáty umistují v učebně a během výuky je využívají jako názornou učební pomůcku. Po skončení vyučovací hodiny plakáty obvykle opět uklidí, nebo nějaký čas ponechají v učebně.

3. Dlouhodobé v učebně - plakáty jsou umístěny v učebně dlouhodobě (obvykle na stěnách, nástěnkách apod.) a dlouhodobě plní své motivační, estetické a edukační funkce. Pozitivní př́nos vhodně designovaných a umístěných plakátů byl pro tuto metodu prokázán a publikován (Stone, 1998; na Ostravské univerzitě např. Tomiczek, 2016; Kuna, 2016).

4. Dlouhodobě ve společných prostorách školy - tyto plakáty jsou ve školách dlouhodobě umístěny mimo učebny, tedy na chodbě, na schodišti, ve vestibulu, v atriu, v jídelně, u šaten apod. Jak uvádí Osa (2004), plakátům, jako učebním pomůckám, není 
v literatuře věnována dostatečná pozornost. Dokonce ani jedna z předních databází informačnich zdrojü ERIC neobsahuje mnoho odkazů na plakáty, jako samostatné učební pomůcky (Osa, 2004). Po pečlivém prostudování databází informačních zdrojů (nejen ERIC), které jsme provedli v roce 2018, můžeme s tímto tvrzením vyslovit souhlas. A právě plakátům, dlouhodobě umístěným ve společných prostorách škol, byl věnován náš výzkum, konkrétně jejich edukační efektivitě.

\section{Cíle výzkumu a použité metody}

Cílem výzkumu bylo zjistit, zda plakáty umístěné ve společných prostorách škol plní svou edukační funkci a přispívají $\mathrm{k}$ dlouhodobému zvýšení úrovně znalostí žáků druhého stupně základních škol. Dílčími cíli bylo zodpovědět na otázky, zda má na edukační efektivitu plakátů vliv množství informací na plakátu, umístění plakátu, věk a pohlaví žáků.

K výzkumu byly využity tři plakáty o velikosti A1 (autoři návrhu: Jana a Pavel Dostálovi, grafické zpracování: Zdeněk Abendroth).

Plakát č. 1 s názvem Ruční nářadí obsahoval nejmenší množství textu a informací, pouze jednotlivým fotografiím představujícím jednotlivé druhy ručního nářadí jsou přiřazeny jejich názvy.

Plakát č. $2 \mathrm{~s}$ názvem Jak se vyrábí textil obsahoval více informací a plocha věnovaná nonverbálním informacím se zmenšila na úkor textu, který byl soustředěn především v pěti textových polích.

Plakát č. $3 \mathrm{~s}$ názvem Zdroje energie obsahoval nejvíce informací ve více textových polích s největším počtem nonverbálních prvků. Náhled plakátů je na obrázku č. 1 .
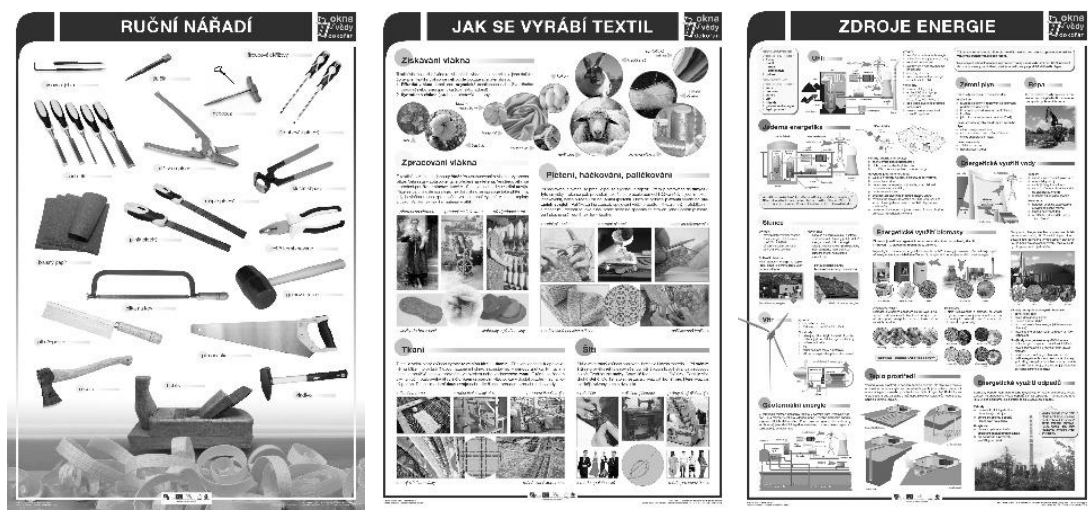

Obr. č. 1: Náhled plakátů vybraných pro experiment.

Pro každý z plakátů byly stanoveny čtyři výzkumné hypotézy:

H 1-1: Po rok trvající aplikaci plakátu č. 1 ve společných prostorách škol dojde ke statisticky významnému zvýšení úrovně vědomostí žáků druhého stupně základních škol souvisejících s obsahem plakátu (analogické hypotézy H 1-2 a H 1-3 byly stanoveny pro plakáty č. 2 a č. 3 ). 
H 2-1: Po rok trvající aplikaci plakátů č. 1 ve společných prostorách škol bude statisticky významný rozdíl ve zvýšení úrovně vědomostí žáků druhého stupně základních škol (souvisejících s obsahem plakátu) vlivem rozdílného umístění plakátů na jednotlivých školách (analogické hypotézy H 2-2 a H 2-3 byly stanoveny pro plakáty č. 2 a č. 3).

H 3-1: Po rok trvající aplikaci plakátu č. 1 ve společných prostorách škol bude statisticky významný rozdíl mezi zvýšením úrovně vědomostí (souvisejících s obsahem plakátu) mezi žáky jednotlivých ročníků (analogické hypotézy H 3-2 a H-3-3 byly stanoveny pro plakáty č. 2 a č. 3 ).

H 4-1: Po rok trvající aplikaci plakátu č. 1 ve společných prostorách škol nebude statisticky významný rozdíl mezi zvýšením úrovně vědomostí souvisejících s obsahem plakátu u chlapců a dívek (analogické hypotézy H 4-2 a H 4-3 byly stanoveny pro plakáty č. 2 a č. 3 ).

Tyto výzkumné hypotézy pro jednotlivé plakáty byly doplněny společnou hypotézou:

H 5: Po rok trvající aplikaci tří různých plakátů ve společných prostorách škol dojde k největšímu zvýšení úrovně vědomostí žáků druhého stupně základních škol souvisejících s obsahem plakátu s nejmenším množstvím obsažených informací (tedy plakátu č. 1).

Hlavní metodou výzkumu byl přirozený pedagogický experiment, kde nezávisle proměnnou byla aplikace třech plakátů ve společných prostorách základních škol, závisle proměnnou byla úroveň vědomostí, indikátorem vědomostí byl počet bodů dosažených v didaktických testech. Výběrovým souborem byli všichni žáci druhého stupně ze tř́ základních škol z Moravskoslezského kraje (přibližně 500 žákủ). Byla zvolena technika jedné skupiny před - po (Kerlinger, 1972), délka experimentu byla 1 rok.

Př́pravná fáze výzkumu zahrnovala př́ípravu výzkumného nástroje. Byly připraveny tři objektivně skórovatelné didaktické testy kognitivní úrovně, tedy pro každý plakát jeden test určený $\mathrm{k}$ testování úrovně znalostí informací obsažených na tomto plakátě. V testech byly využity položky otevřené se stručnou odpovědí (produkční a doplňovací), uzavřené $\mathrm{s}$ výběrem odpovědi a uzavřené přiřazovací. Před vlastním experimentem byly prototypy vytvořených didaktických testů ověřeny na vzorku 51 žáků ze dvou šestých trríd jedné základní školy (na které pak neprobíhal vlastní experiment). Po analýze výsledků ověřování vlastností vytvořených testů byly provedeny korektury dvou položek $\mathrm{v}$ testu $\mathrm{k}$ plakátu č. 2 a jedné položky $\mathrm{v}$ testu $\mathrm{k}$ plakátu č. 3 (především za účelem zvýšení jejich obtížnosti).

Z důvodu usnadnění testování na základních školách byly didaktické testy na školy distribuovány ve vytištěné podobě. Před experimentální manipulací nezávisle proměnné byla úroveň vědomostí měřena vstupními didaktickými testy (pretesty). Následně byly plakáty vyvěšeny. Ve shodě $\mathrm{s}$ cíli výzkumu byly plakáty umístěny ve společných prostorách škol, přičemž byla volena místa, kde se žáci déle zdržují. Protože nás zajímala dlouhodobá edukační efektivita, tedy nikoliv krátkodobý efekt ovlivněný např́klad krátkodobým zvýšením zájmu žáků o nově vyvěšené plakáty, byla úroveň vědomostí měřena výstupními didaktickými testy (posttesty) s ročním odstupem. Měřítkem edukační efektivity jsou vědomosti žáků na konci experimentu ve srovnání s vědomostmi před experimentem indikované rozdílem bodů získaných ve vstupních didaktických testech vůči testům výstupním.

K výše uvedeným hypotézám byly formulovány adekvátní statistické hypotézy, které byly testovány s využitím Wilcoxonova testu (hladina významnosti 0,05 ). Ke zpracování 
získaných dat a jejich statistickému vyhodnocení byl využit software Excel, NCSS a PAST.

\section{Výsledky experimentu}

Na základě realizovaného experimentu po roční aplikaci plakátů ve společných prostorách škol je možné konstatovat, že statisticky významný prrírůstek vědomostí žáků druhého stupně byl s využitím Wilcoxonova testu (hladina významnosti 0,05 ) indikován pouze u plakátu č. $1 \mathrm{~s}$ nejmenším množstvím obsažených informací (obr. č. 2). Protože vypočtená p-hodnota $2,1326 \cdot 10^{-11}$ je menší než zvolená hladina významnosti, můžeme zamítnout nulovou hypotézu.

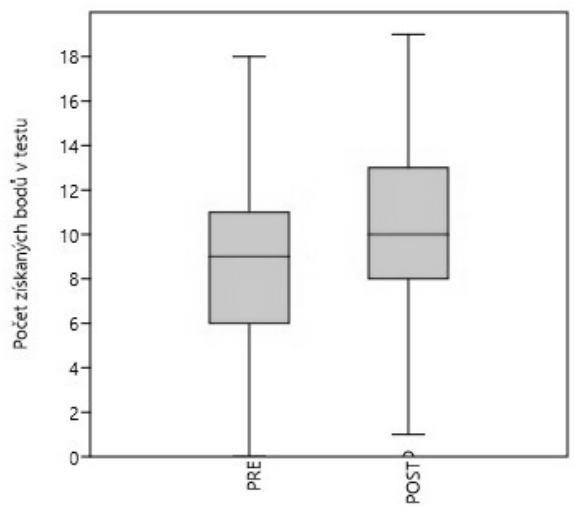

Obr. č. 2: Krabicový graf vizualizujicí počet bodů ziskaných v pretestu (PRE) a v posttestu (POST) pro plakát č. 1 celým výběrovým souborem.

Aritmetický průměr bodů získaných v posttestech ve srovnání s pretesty vzrostl po roční aplikaci plakátu č. 1 o celých $20 \%$, naopak u plakátů č. 2 a 3 nebyl indikován mezi výsledky pretestů a posttestů statisticky významný rozdíl. $Z$ toho sice vyplývá potvrzení hypotéz H 1-1 a H 5, ale naopak vyvrácení hypotéz H 1-2 a H 1-3.

Protože mezi zisky bodů $v$ pretestech a posttestech u plakátů č. 2 a 3 nebyl zjištěn statisticky významný rozdíl, u těchto plakátů tedy nebyl po roční aplikaci pozorován signifikantní prírůstek znalostí, nemá také smysl dále testovat hypotézy H 2-2, H 2-3, H 3-2, H 3-3, H 4-2 a H 4-3.

Graf na obr. č. 3 ilustruje rozdíly v získaných bodech na jednotlivých základních školách. Protože byl $\mathrm{v}$ př́růstku vědomostí u plakátu č. 1 mezi pretestováním a posttestováním indikován mezi jednotlivými školami statisticky významný rozdíl (Wilcoxonovým testem s hladinou významnosti 0,05 byla vždy vzájemně srovnána data získaná na jednotlivých školách - tedy tři dvojice dat), znamená to potvrzení hypotézy H 2-1 o vlivu rozdílného umístění plakátu na jednotlivých školách na výstupní znalosti. 


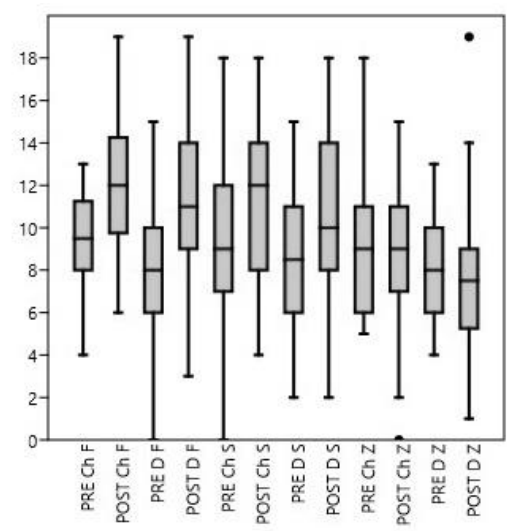

Obr. č. 3: Krabicový graf vizualizující počet bodů ziskaných v pretestu (PRE) a v posttestu (POST) pro plakát č. 1 na různých školách ( $F, S, Z$-označení jednotlivých škol; Ch-chlapci; D-dívky).

Srovnání přírůstku znalostí mezi jednotlivými ročníky dokumentované v grafu na obr. č. 4 přineslo zjištění, že signifikantně vyšší přírůstek znalostí související s roční aplikací plakátu č. 1 byl indikován u vyšších ročníků (u 8. a 9. ročníku), z čehož rezultuje potvrzení hypotézy H 3-1 (s využitím Wilcoxonova testu s hladinou významnosti 0,05 byla vždy vzájemně srovnána data u jednotlivých ročníků - tedy 6 dvojic dat).

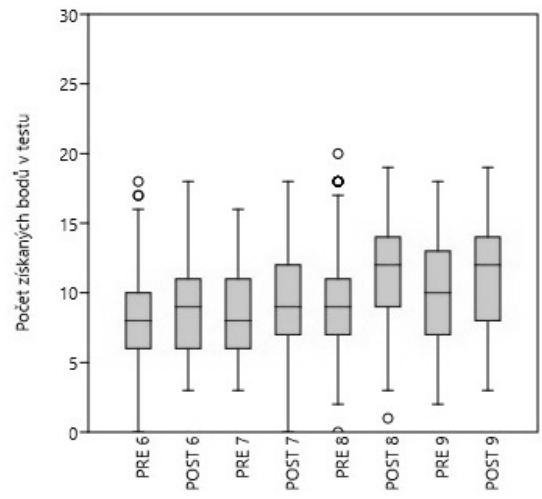

Obr. č. 4: Krabicový graf vizualizující počet bodů ziskaných v pretestu (PRE) a v posttestu (POST) pro plakát č. 1 v jednotlivých ročnících (6., 7., 8. a 9.).

V grafech na obr. č. 5 je srovnán přírůstek znalostí u chlapců a dívek. Po roční aplikaci plakátu č. 1 nebyl indikován statisticky významný rozdíl mezi prrírůstkem znalostí u chlapců a dívek (Wilcoxonův test, hladina významnosti 0,05 , potvrzení hypotézy H 4-1). 

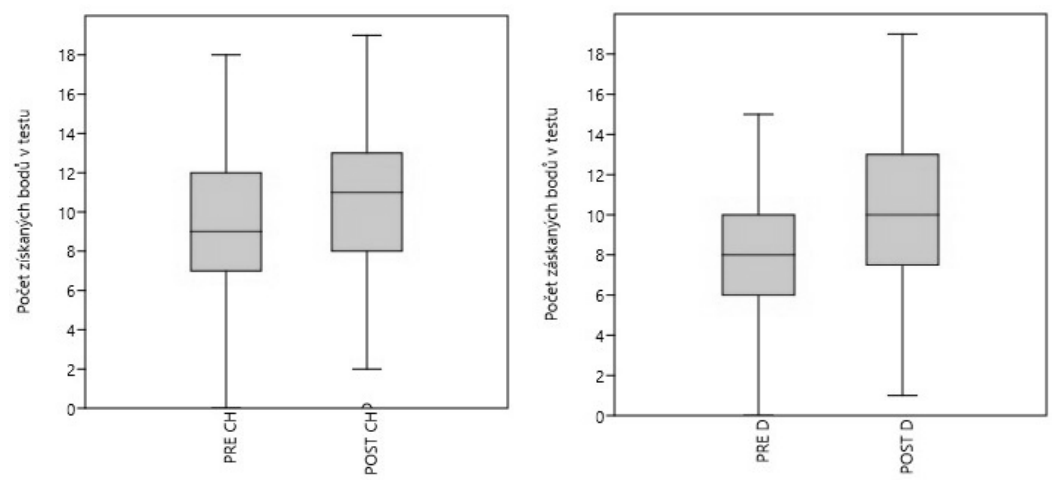

Obr. č. 5: Grafy srovnávajici počet bodi̊ ziskaných v pretestu (PRE) a v posttestu (POST) chlapci (CH) a divkami (D) pro plakát č. 1.

Zajímavým vedlejším zjištěním bylo, že v testech souvisejících s plakátem č. 2 , který byl věnován výrobě textilu, dosáhly dívky statisticky významně více bodů než chlapci. Avšak přibližně stejný rozdíl zde byl mezi výsledky pretestů i posttestů, respektive, jak bylo uvedeno výše, mezi zisky bodů v pretestu a posttestu nebyl zjištěn statisticky významný rozdíl, což je dokumentováno na obr. 6 . Z toho vyplývá, že v testech byla indikována signifikantně vyšší úroveň znalostí děvčat $\mathrm{v}$ oblasti výroby textilu (nesouvisející s aplikací plakátů). V oblasti názvosloví ručního náradí (plakát č. 1) a využívání energetických zdrojů (plakát č. 3) podobné rozdíly mezi chlapci a dívkami na druhém stupni základních škol indikovány nebyly.
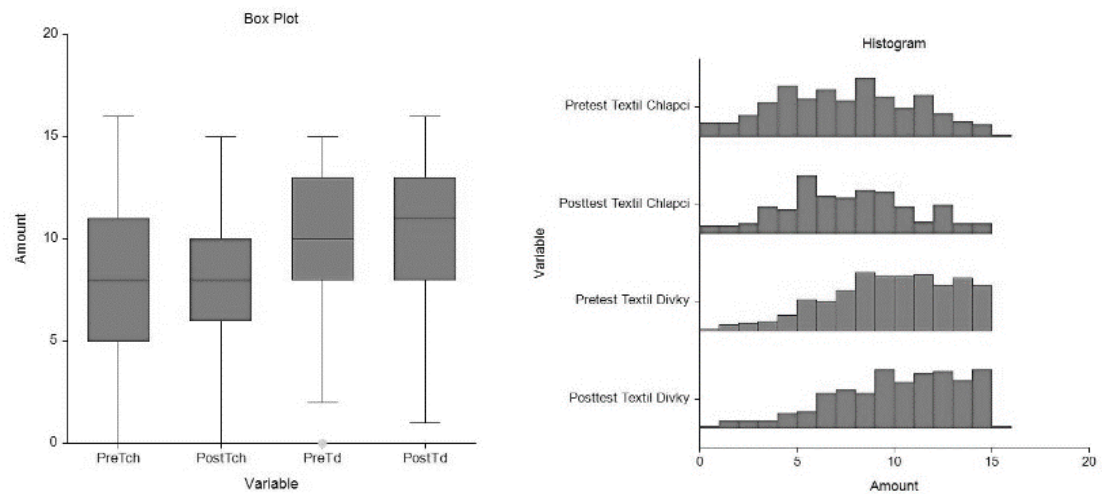

Obr. č. 6: Krabicové grafy srovnávající počty bodů získaných v pretestu chlapci (PreTch), v posttestu chlaci (PostTch), v pretestu divkami (PreTd) a v posttestu divkami (PostTd), doplněné o histogramy četnosti dosažených bodů (pro plakát č. 2). 


\section{Diskuze}

Chceme-li diskutovat výsledky výzkumu, je smysluplné nejprve diskutovat metody, kterými jsme $\mathrm{k}$ těmto výsledkům dospěli. Hlavním cílem bylo zjistit, zda plakáty umístěné ve společných prostorách škol přispějí ke zvýšení úrovně znalostí žáků druhého stupně základních škol. Realizovaný výše popsaný pedagogický experiment je možné označit za obvyklý, stejně jako identifikaci přírůstku znalostí s využitím didaktických testů.

Jako diskutabilnější se může jevit zvolená technika jedné skupiny před - po. Nebyla zvolena technika paralelních skupin, poněvadž pokud jsou plakáty dlouhodobě umístěny ve společných prostorách škol, není reálně možné oddělit kontrolní skupinu, u níž by neproběhla manipulace nezávisle proměnné. Jiná situace by byla, kdyby se výzkum věnoval efektivitě plakátů umístěných v učebně, kdy je možné vytvořit skupinu experimentální, která má přístup do této učebny, a skupinu kontrolní, která př́stup do této učebny nemá (výsledky naším pracovištěm takto realizovaného výzkumu např. Tomiczek, 2016; Kuna, 2016). Byla by zde možnost na jedné škole plakáty aplikovat (skupina experimentální) a na druhé nikoli (skupina kontrolní), ale hlavním argumentem proti takto uspořádanému experimentu byla neexistence totožných škol, kde by bylo možné umístit plakáty na zcela stejná místa, a s tím související hypotéza o vlivu rozdílného umístění plakátů na jejich edukační efektivitu (viz H 2-1), která byla výzkumem potvrzena.

Jako slabina techniky jedné skupiny před - po bývá uváděno ovlivnění výsledků zráním organismu (zvláště tehdy, jestliže časový interval mezi prvním a druhým měřním je dlouhý) (Chráska, 2007). Pokud bychom provedli posttestování po roce na stejné skupině žáků, je takové ovlivnění výsledků pravděpodobné, a to nejen v důsledku o rok vyššího věku žáků při posttestování, ale také tím, že mezi pretestováním a posttestováním probíhá výuka související se zaměřením plakátů. Toto zkreslení výsledků jsme se snažili minimalizovat modifikací techniky před - po tím, že výběrovým souborem při pretestování byli všichni žáci druhého stupně zapojených škol a výběrovým souborem při posttestování byli opět všichni žáci druhého stupně zapojených škol. A protože posttestování proběhlo přesně po roce, měli tedy žáci z výběrových souborů při pretestování i posttestování stejný věk a byli ve stejné fázi vzdělávání.

Naopak problematičtější je fakt, že přibližně čtvrtina žáků se vyměnila (žáci, kteří byli při pretestování v devátém ročníku, školy opustili, a naopak přibyli noví žáci šestých ročníků). Ovlivnění výsledků experimentu konkrétními rozdíly mezi jedinci jsme se snažili minimalizovat velikostí výběrových souborů (přibližně 500). Pro srovnání a kontrolu bylo také provedeno vyhodnocení experimentu, do něhož byli zahrnuti pouze žáci sedmých a osmých ročníků, tedy ti, kteří se účastnili jak pretestování, tak posttestování se zjištěním, že takto upravený experiment neměl na zjištěné výsledky podstatný vliv.

Hlavním zjištěním prezentovaného výzkumu je, že po roční aplikaci plakátů ve společných prostorách škol splnil svou edukační roli pouze plakát s nejmenším množstvím obsažených informací. U ostatních plakátů je možné, že plní svou roli estetickou a motivační, což však nebylo předmětem výzkumu. Dále byl potvrzen předpoklad, že na edukační efektivitu plakátů má podstatný vliv jejich konkrétní umístění a nemá vliv pohlaví žáků.

Při realizaci výzkumu na základních školách jsme se setkávali s názorem, že plakáty nemají žádný význam a pozornost žáku je zúžena pouze na elektronická média. 
Prezentovaný výzkum potvrdil edukační potenciál plakátů s technicky orientovaným obsahem, avšak s pečlivě promyšleným designem, který reflektuje vnímání současných žáků.

Samožrejmě, že provedený experiment je pouze dílčím krůčkem ve výzkumu významu plakátů ve vzdělávání. S cílem dalšího rozšiření znalostí v oblasti edukační efektivity plakátů $s$ technicky zaměřeným obsahem probíhá od podzimu 2018 podobně koncipovaný experiment na dalších deseti základních školách v České republice s podporou projektu OP VVV Pregraduální vzdělávání v učitelských oborech na Pedagogické fakultě Ostravské univerzity (registrační číslo CZ.02.3.68/0.0/16_038/0006778).

Dalším zajímavým námětem vybízejícím k dalšímu zkoumání je indikovaný signifikantní rozdíl ve znalostech chlapců a dívek vstupujících do experimentu.

\section{Závěr}

Využití plakátů s technicky zaměřeným obsahem na základních školách je nepochybně možné doporučit. V situaci, kdy je technickému vzdělávání na základních školách věnována pouze omezená časová dotace, a také další podmínky pro jeho realizaci často není možné označit za optimální, můžou plakáty sloužit jako užitečná učební pomůcka. Pokud se zaměříme pouze na jejich edukační efektivitu, je možné doporučit jejich umístění př́ímo $\mathrm{v}$ učebnách. $Z$ výsledků výzkumu uveřejněných $\mathrm{v}$ tomto článku vyplývá, že pokud mají plakáty umístěné ve společných prostorách škol plnit svou edukační roli, je nutné pečlivě volit jejich umístění a design, jejich sdělení musí být přiměřeně jednoduché.

\section{Literatura}

Boling, E., Eccarius, M., Smith, K., \& Frick, T. (2004). Instructional Illustrations: Intended Meanings and Learner Interpretations. Journal of Visual Literacy, 24(2), 185-204. DOI: 10.1080/23796529.2004.11674612.

Cook, M. P. (2006). Visual representations in science education: The influence of prior knowledge and cognitive load theory on instructional design principles. Science Education, 90(6), 1073-1091. DOI: 10.1002/sce.20164.

David, T. G., \& Wright, B. D. (1975). Learning environments. Chicago: University of Chicago Press.

Eisen, A. (1998). Small-Group Presentations: Teaching "Science Thinking" and Context in a LargeBiolagy Class. Bioscience, 48(1), pp. 53-58. DOI: 10.2307/1313228.

Eker, C. (2016). The effect of posters used as an alternative learning tool on students academic achievement and attitudes towards the course. Journal of Theory and Practice in Education. Vol. 12(1), pp. 103-121. Dostupné z: https://dergipark.org.tr/tr/pub/eku/issue/26699/280881

Fisher, A. V., Godwin, K. E., \& Seltman, H. (2014). Visual Environment, Attention Allocation, and Learning in Young Children. Psychological Science, 25(7), 1362-1370. DOI: 10.1177/0956797614533801.

Gosling, P. J. (1999). Scientist's guide to poster presentations. New York: Kluwer Academic. DOI: $10.1007 / 978-1-4615-4761-7$.

Hasio, C. (2015). Visual Inspirations: The Pedagogical And Cultural Significance Of Creative Posters In The Art Classroom. Journal of College Teaching \& Learning (TLC). 12(1), 39-44. DOI: 10.19030/tlc.v12i1.9068. 
Hrabí, L. (2006). Hodnocení grafické informace učebnic přírodopisu. E-Pedagogium, 6(1), $26-32$.

Hubenthal, M., O'Brien, T., \& Taber, J. (2011). Poster that foster cognition in the classroom: multimédia theory applied to educational posters. Educational Media International. 48(3). pp. 193-207. DOI: 10.1080/09523987.2011.607322.

Chráska, M. (2007). Metody pedagogického výzkumu. Praha: Grada Publishing, a.s.

Janko, T. (2012). Nonverbální prvky v učebnicích zeměpisu jako nástroj didaktické transformace. Brno: Masarykova univerzita.

Kerlinger, F. N. (1972). Základy výzkumu chování: pedagogický a psychologický výzkum.

Praha: Academia.

Kohoutek, R. (1998). Základy sociálni psychologie. Brno: CERM.

Komenský, J. A. (1658). Orbis sensualium pictus. Norimberk.

Kuna, T. (2016). Energetický prümysl a jeho dopady na životní prostředí České republiky: bakalářská práce. Ostrava: Ostravská univerzita.

Mareš, J. (2001). Učení z obrazového materiálu. In J. Čáp \& J. Mareš (Eds.), Psychologie pro učitele (s. 493-503). Praha: Portál.

Martin, S. H. (2002). The Classroom Environment And Its Effects On The Practice

Of Teachers. Journal of Environmental Psychology, 22(1-2), 139-156. DOI:

10.1006/jevp.2001.0239.

Novotný, P. (2007). Vizuální informace ve vybraných učebnicích dějepisu pro 9. ročník základní školy. In T. Janík, P. Knecht, \& V. Najvarová (Eds.), Příspěvky k tvorbě a výzkumu kurikula (s. 133-140). Brno: Paido.

Oblinger, D. G. (2006). Learning spaces. Boulder, CO: Educause.

Oliveira, A. (2009). Poster presentation and learning log: alternatives in assessment at undergraduate and graduate levels. Signótica, 20(2). DOI: 10.5216/sig.v20i2.6491.

O`Neil, C. E. (2001). A Poster Session to Describe Student Experiences in Community Nutrition Agencies. Journal of Nutrition Education, 33(5), 297-298. DOI: 10.1016/s14994046(06)60295-9.

Osa, J. O., \& Musser, L. R. (2004). The role of Posters in Teacher Education Programs. Education Libraries, 27(1), 16-21. DOI: 10.26443/el.v27i1.196.

Peeck, J. (1993). Increasing picture effects in learning from illustrated text. Learning and Instruction, 3(3), 227-238. DOI: 10.1016/0959-4752(93)90006-1.

Pešková, K. (2012). Vizuální prostředky pro výuku reálií v učebnicích němčiny. Brno: Masarykova univerzita.

Rickards, M. (1970). Posters of protest and revolution. New York: Walker.

Ringshausen, G. (1976). Von der Buchillustration zum Unterrichtsmedium. Weinheim: Beltz Verlag.

Spousta, V. (2007). Vizualizace. Gnostický a komunikační prostředek edukologických fenoménů. Brno: Masarykova univerzita.

Stone, N. J., \& English, A. J. (1998). Task Type, Posters, And Workspace Color On Mood, Satisfaction, And Performance. Journal of Environmental Psychology, 18(2), 175-185. DOI: 10.1006/jevp.1998.0084.

Timmers, M. (1998). The Power of the Poster. London: Victoria \& Albert Publications.

Tomiczek, L. (2016). Edukační plakáty pro vzdělávací oblast Člověk a svět práce: bakalárská práce. Ostrava: Ostravská univerzita.

Väisänen, J. (2005). Visual texts in Finish history textbooks. In Bruillard, E., Aamotsbakken, B., Knudsen, S. V., \& Horsley, M. Caught in the web or lost in the textbook? Eighth International Conference on Learning and Educational Media (s. 297-304). Utrecht: IARTEM. Wahla, A. (1983). Strukturní složky učebnic geografie. Praha: SPN. 